DOI: $10.22363 / 2313-1683-2019-16-2-213-223$

UDC 159.99

\title{
Pedagogical Content Knowledge, School Climate and Instructional Effectiveness of Secondary Schools Business Teachers in Ogun State, Nigeria
}

\author{
Abolaji O. Bukki ${ }^{1}$, Margaret M. Dosunmu ${ }^{1}$, Titilola O. Bukki ${ }^{2}$ \\ ${ }^{1}$ Olabisi Onabanjo University \\ Ago Iwoye, Ogun State, Federal Republic of Nigeria \\ ${ }^{2}$ Amazing Grace Kiddies College \\ Ago Iwoye, Ogun State, Federal Republic of Nigeria
}

This research examined the relative influence of pedagogical content knowledge and school climate on instructional effectiveness of secondary schools business teachers in Ijebu Division, Ogun State, Nigeria. Descriptive survey design was adopted for the study. Pedagogical Content Knowledge Scale (PCKS), Organizational Climate Index (OCI) and Teacher Effectiveness Questionnaire (TEQ) were used as the instrument for data collection. The statistical method of analysis used for testing the raised questions were Simple percentage, Pearson Product Moment Correlation (PPMC) and Regression Analysis at 0.05 level of significance. The findings revealed that there was a positive relationship between pedagogical content knowledge, school climate and instructional effectiveness of secondary schools business teachers in Ijebu Division, Ogun State. Furthermore, pedagogical content knowledge, school climate significantly influenced the business teachers' instructional effectiveness in secondary schools. It was recommended among others that principals should ensure that cooperative school climate that can inspire teachers to effectively fulfil their duties is created. The government should persuade and support business teachers to focus on conferences, workshops and seminars that will boost their pedagogical content knowledge in the fulfilment of their duties efficiently.

Key words: pedagogical content knowledge; school climate; instructional effectiveness; teachers; secondary schools

\section{Introduction}

Education is a dynamic instrument of progress, both developed countries and those seeking advancement have embraced it as an apparatus of qualification for affecting national progress. The value of education relies on the excellence of teachers and this influences the instructional quality in the schools accordingly, the teacher is basic to the accomplishment of any educational system. The incapability of the teachers in the classroom interaction would have a bearing on the school success. Studies on teachers'

(C) Bukki A.O., Dosunmu M.M., Bukki T.O., 2019

This work is licensed under a Creative Commons Attribution 4.0 International License 
instructional effectiveness in classes have gained importance in recent years. Teachers' instructional effectiveness is thought to be an imperative school variable that should be investigated even in the area of teaching business subjects. Teachers need to possess various knowledge and skills to get ready for and execute a successful training that will promote students' understanding and learning. However, they not only need to have in-depth knowledge of the subject-matter, instructional method, educational modules, and students, in addition, they should have the capacity to convey this knowledge successfully while instructing (Kilic, 2009).

Pedagogical content knowledge (PCK) can be defined as a capacity to consolidate knowledge of the specific disciplines and how to teach those disciplines. It can clarify that the content knowledge ought to be mixed with the components of the teaching process and the instructional method (Nuangchalerm, 2012). Kilic (2009) defined PCK as having four segments: knowledge of subject-matter (knowing specific subject ideas, actualities, and methodology and the connections between them), knowledge of pedagogy (knowledge of planning a lesson and teaching strategies), knowledge of learners (knowledge of students' common difficulties, errors, and misconceptions), and knowledge of curriculum (knowledge of learning objectives for different grade levels and instructional materials such as innovative manuals, and course books) (Kilic, 2009)

PCK is not quite the same as the knowledge of the subject itself and the general pedagogical knowledge. It includes the knowledge of teaching strategies that incorporate the appropriate methods and prior conceptions, and create a learning environment (Kane \& Russell, 2005; Nuangchalerm, 2012). PCK is viewed as a transformation of teacher knowledge from a variety of domains of knowledge, which includes subject matter knowledge, pedagogical knowledge, and knowledge about the content (Botha \& Reddy, 2011). Earlier research had similarly demonstrated that pedagogical and subject content knowledge of teachers were observed to be critical indicators of teachers' performance and students' accomplishment (Olasehinde-Williams, Yahaya \& Owolabi, 2018; Sultan \& Shafi, 2014).

The significance of the school climate to teachers' effectiveness is additionally applicable to a high degree since it is demonstrative of how well the teacher manages to understand his/her maximum capacity. Hence, the school climate certainly influences the teachers' performance in school (Bai, Heydari \& Niknahad, 2014). The school climate is depicted as the quality and character of school life. School climate depends on students, parents or guardians' and school work force's involvement into school life and reflects standards, objectives, values, interpersonal relationships, educating and learning practices, and organizational structures (The National School Climate Council, 2007). The school climate is a generally continuing nature of the school condition that is experienced by members, influences their conduct, and depends on their aggregate view of conduct in schools. It is vital to portray and analyse the school climate because the atmosphere of a school has a major impact on the organisational behaviour and because the administrators can have a significant positive influence on the development of the image of the school (Adejumobi \& Ojikutu, 2013).

The school climate is a result of social interactions among students and teachers, is impacted by instructive and social qualities, and has been shown to relate to social situations in classrooms and within the school as a whole (Thapa, Cohen, Guffey, \& 
Higgins, 2013). The National School Climate Center (2012) as referred to by Chinelo and Ogbah (2013) uncovered that the school climate is a multidimensional construct that incorporates physical, social and scholastic measurements. How students and staff feel about their school climate (either positive or negative) underlies individual attitudes, practices, and group standards (Chinelo \& Ogbah, 2013). It affects the teachers responsibility for setting out the school vision about where the school is going to, reflects upon the attributes of respect, individual nobility of spirit, trustworthiness, decency, and security. If the school climate neglects to reflect this set of characteristics, then integration, maintenance of sustainability, the establishment of the sense of equality among students with constrained scholarly abilities or not, is absent (Rapti, 2013).

School climate is made up of several factors and behaviours that determine people's attitude, feelings, and behaviour within the school or organization. The correlation between the school climate and the PCK cannot be overruled because if the knowledge of pedagogical content is the transformation and mixing of knowledge and beliefs and pedagogy into instructional achievements in the classroom, the PCK of a teacher enables content issues and expertise to be tailored to the learner's skills and interests. The PCK integrates unique knowledge, beliefs and values that are all imperative for improving professional teaching experience. They are: (a) knowledge of subject matter content, (b) pedagogical knowledge, (c) knowledge of curriculum, (d) student knowledge (how they understand their conceptions and common errors), (e) understanding of teaching functions, and (f) general pedagogical knowledge (Amade-Escot, 2000). Effective teaching will take place if teachers integrate all PCK factors and observe them in their specific teaching environments.

School climate influences teacher motivation and commitment at work, work fulfilment, and adequacy. In an organization with a high degree of the humanistic relationship, collegiality, and interest, the teaching effectiveness is high, triggering a higher success of education, too (Babu \& Kumari, 2013; Bai, Heydari \& Niknahad, 2014). Several past studies had uncovered that school climate had an effect on teachers' productivity, teachers' innovation and morale (Oder \& Eisenschmidt, 2018; Eboka, 2017; Bai, Heydari \& Niknahad, 2014; Okoye, 2012; Yusuf \& Adigun, 2010). While pedagogical content knowledge and school climate are believed to influence teachers viability in some science-related subjects, little is thought about its impact on business studies teachers' instructional effectiveness, if there are any of such studies at all, it is not to the knowledge of this researcher; consequently the justification of this investigation. It is on the basis of this premise that the researcher seeks to find out the influence of pedagogical content knowledge and school climate on the instructional effectiveness of secondary schools business teachers in Ijebu-Division, Ogun State, Nigeria.

The objective of this study was to examine the influence of the pedagogical content knowledge and school climate on the instructional effectiveness of secondary schools business teachers in Ijebu Division, Ogun State, Nigeria. The specific objectives are:

- to assess the relationship among pedagogical content knowledge, school climate and instructional effectiveness of business teachers in secondary schools;

- to examine the influence of pedagogical content knowledge on the teacher's instructional effectiveness; 
- to determine to what extent the school climate affects the teacher's instructional effectiveness in the secondary school.

The following research questions are raised to guide the study:

1) What is the relationship between pedagogical content knowledge, school climate and instructional effectiveness of business teachers in the secondary schools?

2) What is the influence of pedagogical content knowledge on the business teacher's instructional effectiveness?

3) To what extent does the school climate affect the business teachers' instructional effectiveness in the secondary schools?

\section{Methodology}

The descriptive research design was adopted for this study. The target population is 199 business studies teachers of junior secondary schools in Ogun State. A sample of 120 respondents was selected for this study. A simple random sampling technique was used to select $60 \%$ of the teachers in the division.

Three research instruments were used to collect data. The instruments are Pedagogical Content Knowledge Scale (PCKS), Organizational Climate Index (OCI) and Teacher Effectiveness Questionnaire (TEQ).

Pedagogical Content Knowledge Scale (PCKS) developed by Aksu, Metin, and Konyalioglu (2014) consisted of 50 items on a five point rating scale. The CronbachAlpha internal integrity coefficient of the scale was found to be 0.967 .

The Organizational Climate Index (OCI) was used to measure school climate. It is a short descriptive measure for schools (Hoy et al., 2002). It is a 27-item 4-point Likerttype scale that assesses critical aspects of the school workplace with $\mathrm{RO}$ - rarely occurs, $\mathrm{SO}$ - sometimes occurs, OO - often occurs, VFO - very frequently occurs. The OCI has four dimensions: collegial leadership, teacher professionalism, academic press, and institutional vulnerability to the community. The reliability scores for each dimension were as follows: Collegial Principal Behaviour (.94), Professional Teacher Behaviour (.88), Achievement Press (.92), and Institutional Vulnerability (.87).

For measuring teacher effectiveness, the scale developed by Sujata Mishra (2013) was adopted. The instrument assesses teacher effectiveness by 48 items on the innovations implemented in the school and the changes they created in the school performances on a five-point Likert scale from level 1 (strongly agree) to level 5 (strongly disagree). The instrument gave high Cronbach Alpha Coefficient which is 0.925 for teacher effectiveness.

The researcher personally visited the schools that were selected for the study. The permission was sought from the school management to allow administering the questionnaire. The respondents were asked to fill in the questionnaire independently before returning them to the researcher. One hundred and twenty (120) questionnaires were distributed but one hundred and seventeen (117) were properly filled in and retrieved back from respondents. Therefore, the analyses were based on the 117 questionnaires properly filled in representing $97.5 \%$ return rate.

Simple percentages, Pearson Product Moment Correlation (PPMC) and Regression analysis at 0.05 level of significance were used to analyse the raised research questions of this study. 


\section{Results}

\section{Demographic Characteristics of Respondents}

Distribution of respondents' demographic characteristics

\begin{tabular}{llcc}
\hline \multicolumn{1}{c}{ Demographic Variables } & \multicolumn{1}{c}{ Options } & Frequency & Percentage (\%) \\
\hline Gender & Male & 51 & 43.6 \\
& Female & 66 & 56.4 \\
& Total & $\mathbf{1 1 7}$ & $\mathbf{1 0 0}$ \\
& Below $25 \mathrm{yrs}$. & 24 & 20.5 \\
& $26-30$ yrs. & 37 & 31.6 \\
& $31-40$ yrs. & 46 & 39.3 \\
& $41-50$ yrs. & 10 & 8.5 \\
& Total & $\mathbf{1 1 7}$ & $\mathbf{1 0 0}$ \\
Highest Level of Education & NCE & 12 & 10.3 \\
& B.Sc (Ed) / B.Ed & 88 & 75.2 \\
& PGDE & 10 & 8.5 \\
& M.Sc/M.Ed & 7 & 6 \\
Years in Teaching Service & Total & $\mathbf{1 1 7}$ & $\mathbf{1 0 0}$ \\
& 1-10 yrs. & 104 & 88.9 \\
& 11-20 yrs. & 13 & 11.1 \\
& Total & $\mathbf{1 1 7}$ & $\mathbf{1 0 0}$ \\
\hline
\end{tabular}

Table 1 presents the distribution of respondents' demographic data. The result of the analysis showed that $51(43.6 \%)$ respondents are male while $66(56.4 \%)$ respondents are female. For the age, $24(20.5 \%)$ are below 25 years, 37 (31.6\%) are within $26-30$ years, $46(39.3 \%)$ are within $31-40$ years and $10(8.5 \%)$ are within $41-50$ years. For the marital status, $44(37.6 \%)$ respondents are single, $70(59.8 \%)$ respondents are married, $2(1.7 \%)$ respondents are divorced and $1(.9 \%)$ respondent is widowed. This analysis showed that $12(10.3 \%)$ respondents are NCE holders, $88(75.2 \%)$ respondents hold B.Sc $(\mathrm{Ed}) / \mathrm{B} . \mathrm{Ed}$ certificates, $10(8.5 \%)$ respondents holds PGDE certificates and $7(6 \%)$ respondents hold M.Sc/M.Ed certificates. Furthermore, the analysis showed that 104 (88.9\%) respondents have $1-10$ years teaching experience and $13(11.1 \%)$ respondents have $11-20$ years teaching experience.

\section{Test of Research Questions}

Research Question One. What is the relationship among pedagogical content knowledge, school climate and business teachers' instructional effectiveness of the secondary schools?

Table 2

Relationship among the pedagogical content knowledge (PCK), school climate (SC) and business teachers' instructional effectiveness (IE)

\begin{tabular}{lccccc}
\hline \multicolumn{1}{c}{ Variables } & Mean & $\begin{array}{c}\text { Standard } \\
\text { deviation }\end{array}$ & PCK & SC & IE \\
\hline Pedagogical Content Knowledge (PCK) & 59.547 & 10.982 & 1 & & \\
School Climate (SC) & 51.992 & 5.605 & $.570^{\star *}$ & 1 & \\
Instructional Effectiveness (IE) & 61.435 & 11.988 & $.204^{\star}$ & $.199^{\star}$ & 1 \\
\hline
\end{tabular}

Notes: ${ }^{\star} p \leq 0.05$ (2-tailed); ${ }^{* \star} p \leq 0.01$ (2-tailed). 
Table 2 presents the mean scores and standard deviations of the responses to the variables measured in the study. For PCK, the mean score - 59.54, standard deviation 10.98; School Climate, the mean score - 51.99, standard deviation - 5.60; and Teachers' Instructional Effectiveness, the mean score - 61.43; standard deviation - 11.98. It also showed that there is a significant positive relationship between pedagogical content knowledge and school climate $(r=.570 ; p \leq .01)$; there is a significant positive relationship between pedagogical content knowledge and teachers' instructional effectiveness $(r=.204$; $p \leq .05)$; and there is also a significant positive relationship between school climate and teachers' instructional effectiveness $(r=.199 ; p \leq .05)$. This implies that there was a significant relationship between PCK, school climate and the secondary school business teachers' instructional effectiveness.

Research Question Two. What is the influence of pedagogical content knowledge on the teacher's instructional effectiveness?

Table 3

Summary of multiple regression analysis of the influence of PCK on the teachers' instructional effectiveness

\begin{tabular}{lccccc}
\hline \multicolumn{1}{c}{ Model } & Sum of Squares & Df & Mean Square & $F$ & $p$ \\
\hline Regression & 693.679 & 1 & 693.679 & 14.993 & .000 \\
Residual & 15977.091 & 115 & 138.931 & & \\
Total & 16670.769 & 116 & & & \\
\hline
\end{tabular}

Summary of Model: $R=0.204 ; R$ square $=0.042 ;$ Adjusted $R$ square $=0.033 ;$ Standard Error $=11.78691$.

Table 3 revealed the influence of pedagogical content knowledge to the prediction of teachers' instructional effectiveness $(F=14.993 ; p \leq .000)$. This means that PCK influenced teachers' instructional effectiveness. The analysis also yielded a co-efficient of multiple regressions $(R)$ of .204 with corresponding $R^{2}$ of .042 indicating that the independent variable accounted for $4.2 \%$ of the total variance in teachers' instructional effectiveness in secondary schools. Therefore, the postulated research question two concludes thus that PCK had a significant influence on the instructional effectiveness of secondary schools business teachers in Ijebu Division, Ogun State, Nigeria.

Research Question Three. To what extent does the school climate affect the teacher's instructional effectiveness in the private secondary schools?

Table 4

Summary of multiple regression analysis of the influence of the school climate on the teachers' instructional effectiveness

\begin{tabular}{lccccc}
\hline \multicolumn{1}{c}{ Model } & Sum of Squares & Df & Mean Square & $F$ & $p$ \\
\hline Regression & 663.011 & 1 & 663.011 & 4.463 & .031 \\
Residual & 16007.758 & 115 & 139.198 & & \\
Total & 16670.769 & 116 & & & \\
\hline
\end{tabular}

Summary of Model: $R=0.199 ; R$ square $=0.040 ;$ Adjusted $R$ square $=0.031 ;$ Standard Error $=11.79822$.

Table 4 revealed the influence of the school climate on the prediction of teachers' instructional effectiveness $(F=4.463 ; p \leq .05)$. This means that school climate influenced teachers' instructional effectiveness. The analysis also yielded a co-efficient of multiple 
regressions $(R)$ of .199 with corresponding $R^{2}$ of .040 indicating that the independent variable accounted for $4 \%$ of the total variance in teachers' instructional effectiveness in private secondary schools. Therefore, the postulated research question three concluded that school climate had a significant influence on the instructional effectiveness of the secondary schools business teachers in Ijebu Division, Ogun State, Nigeria.

\section{Discussion}

The result of Question One research indicated that there was a significant and positive relationship between PCK, school climate, and teachers' instructional effectiveness. The implication of this is that for effective teaching of Business studies to take place in our schools, better school climate and pedagogical content knowledge of teachers should be considered in order to have appropriate preparation and delivering of lessons that will achieve its objectives. This was in line with the findings of Sultan and Shafi (2014) that indicated that teachers' subject knowledge predicted the school performance. This result is also in consonance with the assertion of Rivkin, Hanushek, and Kain (2005) that school climate is a perfect representation of the physical and psychological aspects of the school that are more vulnerable to change, which provide the essentials necessary for teaching and learning to be effective.

The result of the research of Question Two also indicated that PCK had a significant influence on the instructional effectiveness of the secondary schools business teachers in Ijebu Division, Ogun State, Nigeria. This result is in consonance with the findings of Olasehinde-Williams, Yahaya and Owolabi, (2018) who revealed that the pedagogical and subject content knowledge of teachers significantly predicted teachers' performance and students' achievement.

Furthermore, the result of Question Three research revealed that the school climate had a significant influence on the instructional effectiveness of the secondary schools business teachers in Ijebu Division, Ogun State, Nigeria. The finding implies that the teachers' instructional effectiveness is a product of the school climate and that a better school climate and conducive environment would create an atmosphere that would enhance the teachers' instructional effectiveness. This result corroborated the findings of Ozgan and Toprak (2012) that discovered that teachers' perceptions, their interactions with students, problem-solving strategies, learning habits, perceptions about learning, and how these perceptions are transferred to the student are of high importance in creating an effective class. It also supported the assertion of Bai, Heydari, and Niknahad (2014) that school climate definitely affects the teacher's performance in school.

\section{Conclusions}

The objective of this study was to find out the influence of the pedagogical content knowledge and school climate on the instructional effectiveness of the secondary schools business teachers in Ijebu Division, Ogun State, Nigeria. With the result of the analyses, it can, therefore, be concluded that there was a significant relationship between the pedagogical content knowledge and school climate, and there was also a significant relationship between the pedagogical content knowledge and instructional effectiveness 
of the secondary schools business teachers in Ijebu Division, Ogun State, Nigeria. Furthermore, the pedagogical content knowledge and school climate had a significant influence on the instructional effectiveness of the secondary schools business teachers in Ijebu Division, Ogun State, Nigeria.

\section{Recommendations}

Based on the findings of the present research, the following are hereby recommended.

1. The Principals and School Authorities should ensure that the cooperative school climate that can inspire teachers to viably carry out their duties is made or created.

2. The government should persuade and support Business teachers to focus on conferences, workshops, and seminars that will boost their pedagogical content knowledge in carrying out their duties productively.

3. The government should inspire and encourage mentoring practice among teachers in schools; the veterans with skilled pedagogical content knowledge should be compelled to serve as mentors for the young teachers.

4. The Ministry of Education officials should always ensure that effective supervisory team is made available to keep an eye on the improvement of each teacher during class sessions.

\section{References}

Adejumobi, F.T., \& Ojikutu, R.K. (2013). School climate and teacher job performance in Lagos state Nigeria. Discourse Journal of Educational Research, 1(2), 26-36. Retrieved from: www.resjournals. org/IJER

Akiri, A.A., \& Ugborugbo, N.M. (2009). Teachers' effectiveness and students' academic performance in public secondary schools in Delta State, Nigeria. Stud. Home Comm. Sci., 3(2), 107-113.

Aksu, Z., Metin, M., \& Konyalioglu, C. (2014). Development of the Pedagogical Content Knowledge Scale for pre-service teachers: the validity and reliability study. Mediterranean Journal of Social Sciences, 5(20), 1365-1377.

Amade-Escot, C. (2000). The contribution of two research programs on teaching content: "Pedagogical Content Knowledge" and "Didactics of Physical Education". Journal of Teaching in Physical Education, 20(1), 78-101.

Babu, A., \& Kumari, M. (2013). Organizational climate as a predictor of teacher effectiveness. European Academic Research, 5, 553-568.

Bai, N., Heydari, M., \& Niknahad, S. (2014). The relationship between School Organizational Climate and Physical Education Teachers' Effectiveness. Research Journal of Sport Science, 2(1), 27-31. Retrieved from: http://www.rjssjournal.com

Botha, M.L. \& Reddy, C.P.S. (2011). In-service teachers' perspectives of pre-service teachers' knowledge domains in science. South African Journal of Education, 31, 257-274.

Chinelo, O.D., \& Ogbah, R. (2013). The School Climate: Challenges Facing Principals in Secondary Schools in Delta State of Nigeria. Journal of Emerging Trends in Educational Research and Policy Studies (JETERAPS), 4(1), 53-63. Retrieved from: jeteraps.scholarlinkresearch.org

Eboka, O.C. (2017). Influence of School Climate on Teachers Morale in Public Secondary Schools in Delta State. IOSR Journal of Research \& Method in Education (IOSR - JRME), 7(1), 19-24. Retrieved from: http://dx.doi.org/10.9790/7388-0701031924 
Greenway, G. (2017). The relationship between school climate and student achievement. Doctoral Dissertation. Georgia Southern University, Georgia.

Hoy, W.K., Smith, P.A., \& Sweetland, S.R. (2002). The development of the organizational climate index for high schools: its measure and relationship to faculty trust. High School Journal, 86(2), 38.

Kane, R., \& Russell, T. (2005). Reconstructing knowledge in action: Learning from the authority of experience as a first-year teacher. In C. Power et al. (Eds), Teacher Professional Development in Changing Conditions. Netherlands: Springer.

Kilic, H. (2009). Pedagogical Content Knowledge of Pre-Service Secondary Mathematics Teachers. A Dissertation of University of Georgia, Geogia. Retrieved from: https://getd.libs.uga.edu/pdfs/ kilic_hulya_200908_phd.pdf

The National School Climate Centre (2012). What is school climate? New York, NY: 10018. Retrieved from: www.schoolclimate.org/climate/

The National School Climate Council (2007). The school climate challenge; narrowing the gap between school climate research and school climate policy, practice guidelines and teacher Education Policy. Retrieved from: http://nscc.cssee.net; http://wwwesc.org/school-climate

Nuangchalerm, P. (2012). Enhancing Pedagogical Content Knowledge in Preservice Science Teachers. Higher Education Studies, 2(2), 66-71. Retrieved from: http://dx.doi.org/10.5539/hes.v2n2p66

Oder, T., \& Eisenschmidt, E. (2018). Teachers' perceptions of school climate as an indicator of their beliefs of effective teaching. Cambridge Journal of Education, 48(1) 3-20. Retrieved from: https:// www.tandfonline.com/doi/abs/10.1080/0305764X.2016.1223837

Okoye, F.N. (2012). Influence of school climate on educational innovations in Nsukka Education Zone of Enugu State. An MED Dissertation. University of Nigeria, Nsukka.

Olasehinde-Williams, F., Yahaya, L. \& Owolabi, H. (2018). Teachers' Knowledge Indices as Predictors of Secondary School Students' Academic Achievement in Kwara State, Nigeria. IAFOR Journal of Education, 6(1), 73-90.

Ozgan, H., \& Toprak, M. (2012). Classroom effects on the effectiveness of a School. Journal of Educational and Instructional Studies in the World, 2(2), 102-109.

Rapti, D. (2013). School Climate as an Important Component in School Effectiveness, Academicus International Scientific Journal, 8, 110-125. Retrieved from: http://www.academicus.edu.al/nr8/ Academicus.pdf

Rivkin, S.G., Hannushek, E.A. \& Kain, J.F. (2005). Teachers, schools, and academic achievement. Econometrical, 73(2), 417-458.

Sultan, S., \& Shafi, M. (2014). Impact of perceived teachers' competence on students' performance: evidence for mediating/moderating role of class environment. I-manager's Journal of Psychology, 1(11), 10-18.

Thapa, A., Cohen, J., Guffey, S., \& Higgins D.A. (2013). A review of school climate research. Review of Educational Research, 83, 357-385. Retrieved from: https://k12engagement.unl.edu/ REVIEW\%20OF\%20EDUCATIONAL\%20RESEARCH-2013-Thapa-357-85.pdf

Yusuf, M.A., \& Adigun, J.T (2010). The influence of school climate change on teachers' productivity and students' achievement. Journal of Research in National Development, 8(2).

\section{Article history:}

Received: 25 April 2019

Revised: 28 May 2019

Accepted: 30 May 2019 
For citation:

Bukki, A.O., Dosunmu, M.M., \& Bukki, T.O. (2019). Pedagogical Content Knowledge, School Climate and Instructional Effectiveness of Secondary Schools Business Teachers in Ogun State, Nigeria. RUDN Journal of Psychology and Pedagogics, 16(2), 213-223. http://dx.doi. org/10.22363/2313-1683-2019-16-2-213-223

\title{
Bio Notes:
}

Abolaji O. Bukki, Ph.D., is a lecturer in the Department of Educational Management and Business Studies at Olabisi Onabanjo University (Ago Iwoye, Ogun State, Nigeria). His research focuses on the teaching and learning of business education, business teachers' professional development, managing change and innovations and business subjects methodological approaches. E-mail: abarngbenga@yahoo.co.uk

Margaret Moronke Dosunmu, Ph.D., is a lecturer in the Department of Educational Management and Business Studies at Olabisi Onabanjo University (Ago Iwoye, Ogun State, Nigeria). Her research focuses on employability skills, workplace learning, business education and secretarial studies. E-mail: akinmoe2007@yahoo.com

Titilola O. Bukki is a counselor and a teacher at Amazing Grace Kiddies College (Ago Iwoye, Ogun State, Nigeria). Her research focuses on students' cognitive and socio-emotional competence development. E-mail: bukkikemi@gmail.com

\section{Соотношение педагогических знаний, школьного климата и эффективности преподавания учителей бизнеса в средних школах штата Огун, Нигерия}

\author{
А.О. Букки ${ }^{1}$, М.М. Досунму ${ }^{1}$, Т.О. Букки ${ }^{2}$ \\ ${ }^{1}$ Университет Олабиси Онабанджо \\ Аго Ивой, штат Огун, Федеративная Республика Нигерия \\ 2 Эмэйзинг Грейс Киддис Колледж \\ Аго Ивой, штат Огун, Федеративная Республика Нигерия
}

\begin{abstract}
В исследовании изучалось относительное влияние педагогических знаний и школьного климата на учебную эффективность учителей бизнеса средних школ в округе Иджебу, штат Огун, Нигерия. Одним из методов исследования был описательный дизайн; для сбора данных применялись «Шкала педагогических знаний», «Индекс организационного климата» и «Опросник эффективности учителей»; для статистической обработки - методы описательной статистики, корреляционный анализ Пирсона и регрессионный анализ. В результате было выявлено, что существует положительная связь между педагогическими знаниями, школьным климатом и эффективностью преподавания у учителей бизнеса средних школ в округе Иджебу, штат Огун, Нигерия. На основе результатов исследования даны рекомендации директорам школ с целью лучшего обеспечения и создания благоприятного школьного климата, способ-
\end{abstract}


ного стимулировать учителей эффективно выполнять свои обязанности; правительство Нигерии должно поддерживать участие учителей средних школ в конференциях, мастер-классах и семинарах, что позволит им повысить педагогические знания для эффективного выполнения своих обязанностей.

Ключевые слова: педагогические знания; школьный климат; учебная эффективность; учителя; средние школы

\section{История статьи:}

Поступила в редакцию: 25 апреля 2019

Принята к печати: 30 мая 2019

\section{Для цитирования:}

Bukki A.O., Dosunmu M.M., Bukki T.O. Pedagogical Content Knowledge, School Climate and Instructional Effectiveness of Secondary Schools Business Teachers in Ogun State, Nigeria (Coотношение педагогических знаний, школьного климата и эффективности преподавания учителей бизнеса в средних школах штата Огун, Нигерия) // Вестник Российского университета дружбы народов. Серия: Психология и педагогика. 2019. Т. 16. № 2. С. 213-223. http://dx.doi.org/10.22363/2313-1683-2019-16-2-213-223

\section{Сведения об авторах:}

Букки Аболаджи O., Ph.D., преподаватель кафедры управления образованием и бизнесисследований, Университет Олабиси Онабанджо (Аго Ивой, штат Огун, Нигерия). E-mail: abarngbenga@yahoo.co.uk

Досунму Mapzapem M., Ph.D., преподаватель кафедры управления образованием и бизнесисследований, Университет Олабиси Онабанджо (Аго Ивой, штат Огун, Нигерия). E-mail: akinmoe2007@yahoo.com

Букки Титилола О., консультант и учитель в Эмэйзинг Грейс Киддис Колледж (Аго Ивой, штат Огун, Нигерия). E-mail: bukkikemi@gmail.com 